\title{
Drivers of the Formalization of Banking Supervision
}

\subsection{INTRODUCTION}

Chapters 2-9 examined the early history and formalization of banking supervision in eight countries (the United States (US), Japan, Sweden, Germany, Switzerland, Belgium, France, and the United Kingdom (UK)). The purpose of this chapter is to compare these cases in an effort to identify common/unique drivers of the formalization process.

A key finding of this book is that the process of formalization of banking supervision differed among various countries. This observation contradicts the popular view that financial crises have always been the main drivers of major financial regulatory reforms. While this was true in countries such as Switzerland and Belgium, it was not the case in Japan, Sweden, or France.

We identified supporting evidence for our finding, including the fact that the institutions of banking supervision were often formalized incrementally. In complex policymaking contexts, the economic, political, and social interests of various stakeholders shaped the institutional setup. This incremental formalization process was affected by the evolution of the banking sector, the growing responsibilities of the government, the advent of the general public as users of financial services, and the resulting development of the finance industry.

These findings are partly the result of our understanding of the formalization process, whereby institutional change requires more than legislation (e.g., the introduction of a banking act). Notably, we found

E. Hotori et al., Formalization of Banking Supervision, https://doi.org/10.1007/978-981-16-6783-1_10 
that the formalization process was longer than anticipated and far from straightforward. Indeed, our selection of the beginning and end points of several countries' formalization processes might be considered controversial, and we are aware that the accounts presented in this book omit some aspects of the history of banking supervision in several countries. However, the time points we selected are based on the definition of institutional "formalization" presented in Chapter 1 , and we believe that this is the best way to represent the process of formalization of banking supervision.

In this chapter, the process of formalization of banking supervision in the eight countries examined, with particular emphasis on the early stages of development, is compared from the following seven perspectives: (a) charter requirements, (b) banknote issuance, (c) liability rules, (d) ensuring the public's trust, (e) financial crises, (f) economic control, and (g) financial globalization.

\subsection{OVERVIEW}

Table 10.1 summarizes the important elements of the formalization of banking supervision including the drivers of the process of formalization of banking supervision in the eight countries examined.

Although each country looks quite different in important ways, commonalities and/or similarities are also observable. Formal banking supervision emerged much earlier in the US, Japan, and Sweden than in Germany, Switzerland, Belgium, France, and the UK. However, in every case examined, the progression to complete formalization took several years or decades as a consequence of a combination of incremental organizational learning and a gradual shift in the position of the relevant stakeholders. The process of institutional development extended far beyond the time at which the first steps toward a formal banking supervisory system were taken. In almost every case, one or more of the three components, namely, regulation (laws), organization, and enforcement, lagged behind the other components.

Generally, the financial system in developed countries was characterized and defined by indicators such as legal regimes, regional characteristics, and nationality (Allen et al. 1938; Allen and Gale 2000; Hall and Soskice 2001; La Porta et al. 1998). In contrast to the conventional view, the aforementioned seven dimensions place more emphasis on the time frame and evolution of the process of formalization of banking supervision. 


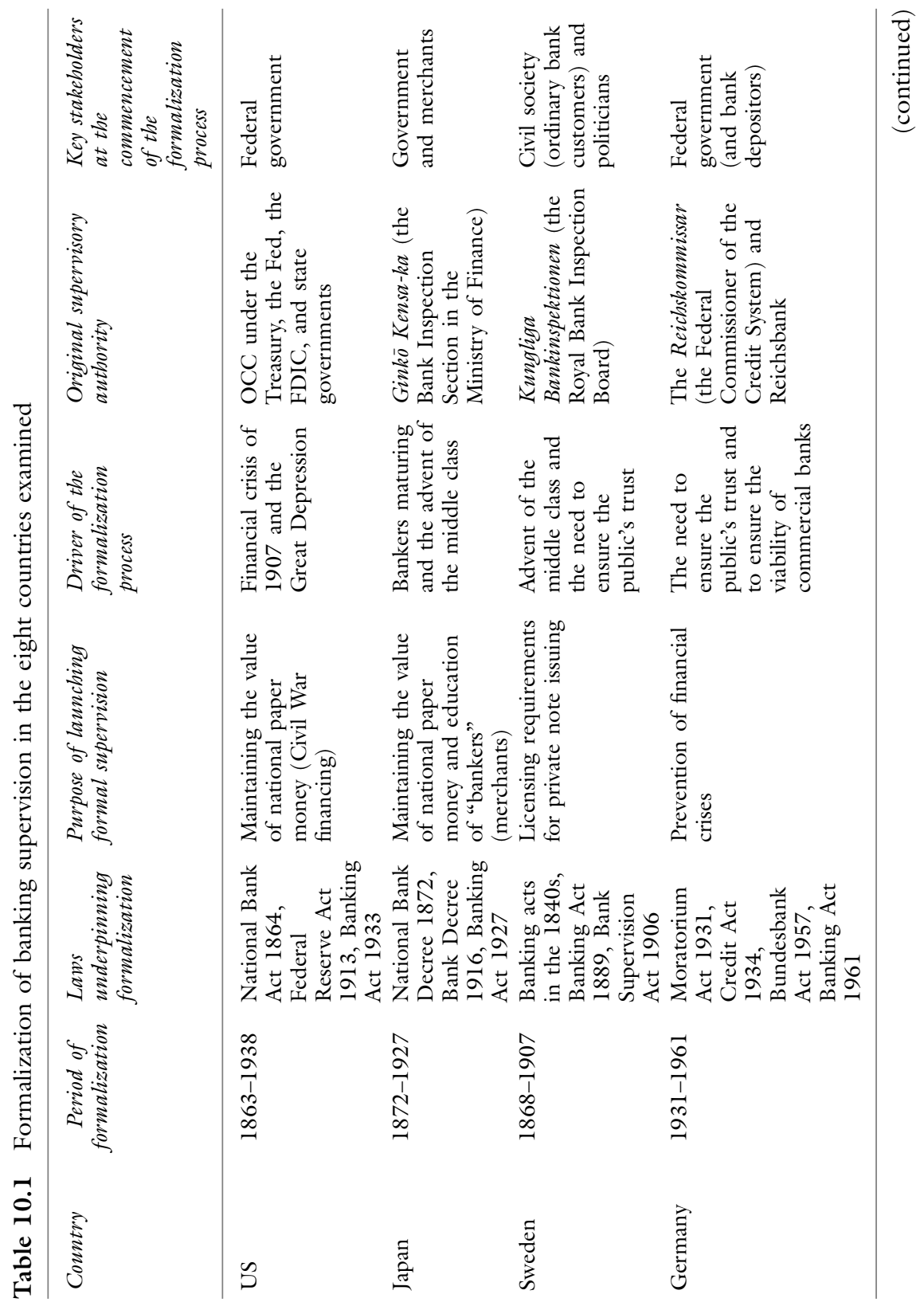




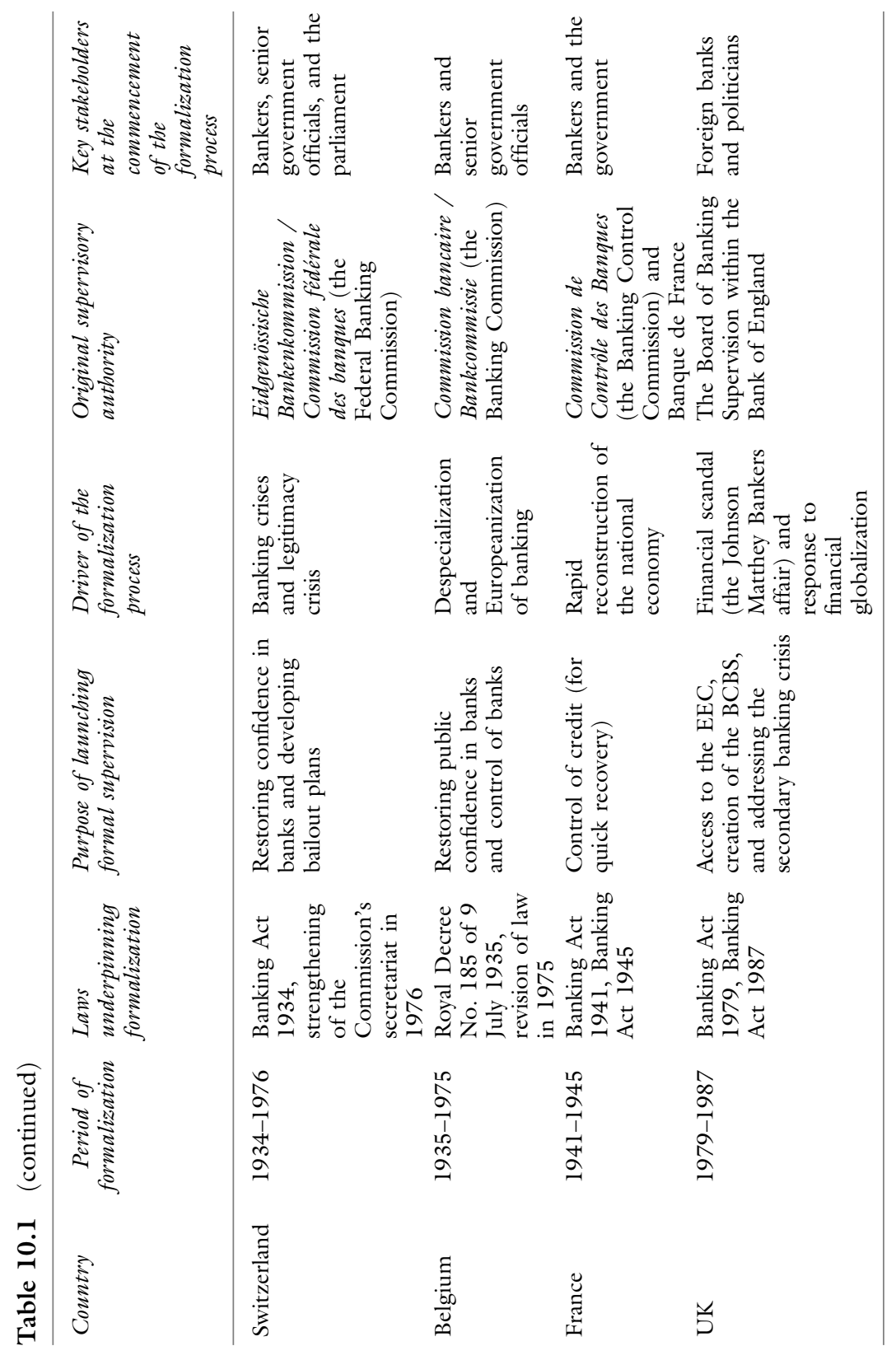


For example, the protection of small depositors was closely related to the advent of the middle class and the spread of universal suffrage in several developed countries. Hence, this chapter also explores the extent to which the time/era can explain the process of formalization of banking supervision in the eight countries examined.

\subsection{Charter Requirements}

One interesting observation is that the early adopters of banking supervision systems, that is, the US, Sweden, and Japan, implemented bank licensing requirements involving strict evaluation procedures. Conversely, the UK, Germany, Switzerland, and Belgium did not exercise such strict charter constraints. Notably, in Germany, the Company Act of 1870 removed the licensing requirement for banks (Berghoff and Köhler 2007). Despite the financial crisis and scandal in the early 1930s in France, licensing requirements remained lax until the introduction of the Banking Act of 1941 .

In the nineteenth century, the UK and Germany enjoyed a "free enterprise" period following the abolition of medieval guild membership, which probably delayed the introduction of the charter system in relation to the commercial banks. The US experienced a "free banking" era from the late 1830 s to 1864 , during which time charter requirements were unnecessary. However, even during this period, chartered banks accounted for the majority of banks in the US. Additionally, state ownership of banks served as a substitute for the charter requirement system. This was also the case in France, where important banks (e.g., Crédit Lyonnais, Société Générale, and BNP) were half state-owned and were therefore practically controlled by the government.

More generally, entry requirements were affected by the preferences of the incumbent actors as a means of ensuring that they maintained their dominant position in the market. Thus, the adoption of either open or restricted entry requirements also depended on the ability of the dominant bankers to influence decision-making during the formalization process. 


\subsection{BANKNote Issuance}

In the second half of the nineteenth century, commercial banks in several countries were allowed to issue banknotes to provide a source of funding. ${ }^{1}$ Private banknotes were generally required to be fully backed by legal tender in the form of gold or other specie, and in some cases, such as the creation of the US Office of the Comptroller of the Currency, banking supervision developed partly to ensure that these note-issuing privileges were not abused. ${ }^{2}$

This was the case in the US. ${ }^{3}$ During the Civil War, the government faced a significant fiscal deficit, and one means of providing war financing involved the issuance of national banknotes. Under the National Currency Act of 1863 and the National Bank Act of 1864, each national bank could issue its own banknotes up to the total amount of its paid-up capital (Section 16). To secure its banknotes, the bank was required to deposit a national bond equal to one-third of the amount of the issuance with the federal government (Section 15). The primary aim of these bondsecured notes was to maintain the value of both the national bonds and the legal tender (greenbacks). Initially, the main aim of bank examinations was to check the health of a national bank to ensure that the value of its banknotes was maintained. The supervision of national banks was stricter than that of state banks, which ceased to issue their own banknotes. ${ }^{4}$ As the merit of issuing banknotes decreased in the late nineteenth century, the focus of bank examinations shifted to "a close scrutiny of the 'business' of the bank" to ensure prudent management (Robertson 1968: 71-73).

\footnotetext{
${ }^{1}$ In Germany, the currency was unified from 1871 to 1875 , and the Reichsbank was created in 1875. Although several note-issuing banks (private banks and savings banks) still existed, they no longer comprised the majority of the banking sector (Krieghoff 2013: 57-62).

${ }^{2}$ In the UK, following the Bank Charter Act 1844, the issuance of bank notes was restricted to the Bank of England in England and Wales. In Scotland and Northern Ireland, every new issuance of banknotes by a commercial bank was required to be $100 \%$ backed by gold in an effort to prevent abuse.

${ }^{3}$ Friedman and Schwartz (1963) describe the transition of the "currency" in the US.

${ }^{4}$ In 1865 , Congress imposed a tax of $10 \%$ on state banknotes, whereupon the remaining state banks ceased to issue their own banknotes. Instead, they relied on deposits, which became the mainstream of the banking business in the twentieth century (Robertson 1968: 53-54).
} 
This was also the case in Japan. Under the National Bank Decree of 1872, each national bank could issue its own banknotes up to $60 \%$ of the total amount of its paid-up capital. ${ }^{5}$ This was a more conservative provision than that in the US. The main aim of the national banking system was to reduce inflation by replacing various forms of legal tender that were declining in value with a more stable (redeemable in specie) national currency. ${ }^{6}$ Following the amendment of the Decree in 1876, national banks were no longer required to reserve specie when issuing banknotes. However, as an issuer of a national currency, every national bank was required to maintain sound management practices and operations. Because the government recognized the possibility of systemic risk and the immaturity of the "bankers" (financial merchants) (Hotori and Wendschlag 2019), on-site bank examinations were conducted almost every year to check the health of each national bank and to educate the inexperienced "bankers" until the creation of the Bank of Japan in 1882 , which enabled the government to unify the issuance of the national currency. From that point, the frequency of on-site bank examinations declined significantly. There were $177,191,54$, and 34 on-site examinations conducted in 1880, 1881, 1882, and 1883, respectively (Hotori 2011: 31).

The importance of note issuing as an element of banking supervision declined during the early twentieth century, as the right to issue banknotes became monopolized by the central bank in most developed countries (Capie et al. 1995: 6). This explains why this element is less important in countries that formalized banking supervision relatively recently.

\subsection{Liability Rules}

In general, a shift from unlimited liability to limited liability of shareholders took place in the second half of the nineteenth century. The

\footnotetext{
${ }^{5}$ Originally, national banknotes were redeemable in specie: each bank was required to hold as much as $40 \%$ of the value of its capital stock in specie as a reserve for redemption. Following the amendment of 1876, the bond deposit amount increased to $80 \%$ of the value of its paid-up capital. The specie reserve provision was abolished, and banks were only required to hold reserves of legal tender equivalent to $20 \%$ of their paid-up capital. Thus, national banknotes were no longer redeemable in specie.

${ }^{6}$ The government aimed to restrain inflation by replacing the various forms of legal tender that were in circulation with a national currency (Kato 1957: 25).
} 
limited liability rule enabled financiers to invest in large projects such as railways, which resulted in further economic development in conjunction with the Industrial Revolution. However, the shift from unlimited to limited liability also enabled ambitious bankers to take excessive risks. One example resulted in the failure of the Western Bank of Scotland in 1857, and the Limited Liability Act of 1855 was severely criticized by a prudent banker (Anonymous 1859). In some but not all countries, banking supervision was formalized in an effort to counter the anticipated increase in such excessive risk-taking. ${ }^{7}$

This was the case in Japan. When the National Bank Decree was enacted, no accompanying corporate/commercial law was implemented. In 1887, the Court first ruled that a shareholder's liability was limited in all cases. Prior to then, the shareholder's liability was basically unlimited even if there was a clause in the articles of association stating that liability was limited (Takamura 1996: 70-73, 128-130). However, under the National Bank Decree (Article 18, Section 12), the liability of a shareholder in a national bank was limited to the amount of his/her paid-up capital. ${ }^{8}$ Hence, it is reasonable to assume that banking supervision was at least partially introduced with the purpose of protecting the creditors/depositors of national banks. ${ }^{9}$

The US case was affected by the unique liability rule, that is, double liability. Under the National Currency Act of 1863 (Section 12), a national bank shareholder was liable for twice the value of his/her shares. Although the OCC directed on- and off-site examinations of national banks, the regulatory and supervisory system prior to 1913 was considered to be relatively "light-touch." The double liability rule imposed a degree of pressure on bank owners to minimize the risk of having

\footnotetext{
${ }^{7}$ For example, this was not the case in the UK. Instead, British bankers learned the importance of sound banking from historical lessons, and thus became prudent bankers (Ross 1998: 2, 166). In the case of Germany, this was more complicated because many joint-stock banks were founded around the time of the war-related boom of 1871. Although the Banking Act of 1875 did not contain any regulatory provisions, the Corporate Act of 1896 included several rules aimed at protecting the public from potentially fraudulent acts by corporations (Krieghoff 2013: 58-60).

${ }^{8}$ Additionally, the nationality of shareholders was limited to Japanese citizens to avoid takeovers by foreigners under the National Bank Decree of 1876 (Ishii 2012: 55-60).

${ }^{9}$ In 1884 , the Ministry of Finance ruled that liability of the shareholders of a nonnational (private) bank should be unlimited. The Mitsui Bank (a zaibatsu bank that adopted the unlimited liability rule) was a renowned example (Takamura 1996: 69-70).
} 
to pay dearly in the case of bankruptcy. Despite the high frequency of bank failures during the period 1865-1913, losses incurred by depositors were relatively small. White (2011: 23-33) pointed out that the owners' personal liability probably worked as an effective incentive for bankers to monitor the bank's status more closely, and to voluntarily liquidate the bank long before it was declared insolvent to avoid excessive losses. Because of this double liability rule, examinations of national banks were seen as complementing the banks' self-disciplinary activities (White 2015: 22-23). The US case illustrates a barter-type relationship between the liability rules and banking supervision.

\subsection{Ensuring the Public's Trust}

The development of deposit-taking banks and the advent of the middle class resulted in a significant increase in the number of individual depositors in all developed countries during the late nineteenth century and early twentieth century. Additionally, by 1925, universal suffrage had spread throughout most developed countries. This meant that politicians, especially during election campaigns, paid more attention to issues relating to average citizens. Thus, the term "protection of depositors" was adopted to ensure that securing the public's trust became an important political aim, ${ }^{10}$ and in several countries, the formalization of banking supervision was partially motivated by the desire to protect individual depositors, even though the deposit insurance system had not yet been widely introduced. ${ }^{11}$

This clearly applied in the case of Sweden. From the 1890s onward, the overall increase in wealth led to a growing proportion of the population being able to save some of their earnings and take out loans to

\footnotetext{
${ }^{10} \mathrm{We}$ are aware that this did not apply in all cases. In the UK, universal suffrage for all men was achieved in 1918, but formal banking supervision was not introduced then. Under the rigid class system that existed, working people's deposits in penny banks were protected by the charity of the rich and the large banks that were the lender of last resort (and/or the Bank of England). The bailout of the Yorkshire Penny Bank in 1911 is a good example (Larson et al. 2010: 127-129). In Germany, universal suffrage was achieved in 1919 under the Weimar Constitution. However, "deposit protection was not on the agenda throughout this period." Instead, banks preferred to become larger as a means of maintaining their liquidity (Krieghoff 2013: 104-105).

${ }^{11}$ The Federal Deposit Insurance Corporation was created by the Banking Act of 1933.
} 
improve the productivity of their farms or small businesses. The government wanted the general population to be able to safely access banking services. Thus, the increase in the number of banks and branches required more resources for the supervision of the commercial banks. In 1905, a thorough investigation was conducted with the aim of obtaining information regarding the future regulation of banks. The investigation report resulted in the creation of a new agency for banking supervision, namely, the Royal Bank Inspection Board (Kungliga Bankinspektionen).

In Japan, the need to provide protection for depositors also prompted the government to complete the process of formalization of banking supervision. Given the increase in the number of commercial bank branches during the interwar period, it seems that the number of ordinary depositors increased dramatically during this period. ${ }^{12}$ Following the implementation of the General Election Law of 1925, universal suffrage for all men was finally realized in the subsequent national and local elections. The next national general election was scheduled for 1927, and the politicians were keen to campaign in advance. The minutes of the Financial System Research Committee meeting held on 13 October 1926 documented the official opinion that from then on, banking supervision should be enhanced for the "protection of depositors." 13 Thus, all banks were forced to disclose their payment reserve report following a bank examiner's inspection under the Banking Act of 1927. Notably, the financial crisis of 1927 took place one month after the implementation of the Banking Act of 1927. Therefore, the financial crisis did not prompt the introduction of the Act.

The salience of deposit insurance as a driver of the formalization of banking supervision also depended on the general population's ability to access banking services. The higher the proportion of households with a bank account at a commercial bank, the more concerned citizens and policymakers were regarding the need for deposit insurance. Conversely, while large sections of the population were effectively excluded from retail banking services, deposit insurance remained less relevant in policy debates on banking supervision.

${ }^{12}$ No official records remain in this regard (Goto 1970: 146-149). However, Osaka Asahi Shimbun (1928) provided a clear illustration of this trend.

13 "Minutes of the Financial System Research Committee in 1926-27," Bank of Japan (1956: 42). 


\subsection{Financial Crises}

Although the difference between banking supervision and bank regulation is not always clear, numerous studies have found that a financial crisis was a critical driver of the formalization of banking supervision in many developed countries (Gigliobianco and Toniolo 2009). A financial crisis provides the initial stimulus, inducing a regulatory reaction, which in turn leads banks to circumvent the regulations by moving into unregulated areas, thereby commencing a new cycle.

The most well-known case is probably that of the US. The financial crisis of 1907 led to the creation of the central banking system and the Federal Reserve (colloquially known as the Fed), which blurred the lines of responsibility for banking supervision between the OCC and the Fed (and the state governments). The supervisory system was already formalized for national banks, while supervision of state banks was relatively lax. The Great Depression in the early 1930s was the catalyst for the creation of a comprehensive banking supervisory system. Following the Banking Act of 1933 and the creation of the Federal Deposit Insurance Corporation (FDIC), all commercial (national and state) banks were subject to supervision by the OCC, the Fed, the FDIC, and/or state governments. ${ }^{14}$ Moreover, the Banking Act of 1935 granted federal supervisors permanent discretionary authority in relation to bank charters.

Switzerland provides another example of this situation. As a result of the 1931 banking crisis in Europe, two large banks, the Banque d'Escompte Suisse and the Schweizerische Volksbank, called for bailout assistance in an effort to avoid bankruptcy. Thus, the 1934 Banking Act was introduced and an independent supervisory agency, the eidgenössische Bankenkommission or Federal Banking Commission (FBC), was created. Although the supervisory activities of the FBC heavily depended on private auditing firms, one of the important roles of the $\mathrm{FBC}$ was to verify banks' compliance with liquidity and equity ratios and to confirm the annual audit of every bank.

Additionally, the severe economic and banking crisis of the early 1930s led to an important reform of the banking system in Belgium. Following

${ }^{14}$ The Federal Reserve Act of 1913 included specific provisions for the supervision of member banks. However, it was not until 1938 that the OCC, the FRB, and the FDIC agreed to a formal division of responsibilities in relation to the examination function (Robertson 1968: 105-112, 125-128). 
complex political debate, Royal Decree no. 185 of 9 July 1935 established a new institution to undertake the supervision of commercial deposit banks: the Commission Bancaire (Banking Commission). Notably, the supervisory measures of the Banking Commission were inspired by the Swiss banking supervisory system (especially the reliance on private auditing firms), which provided considerable leeway for the continuation of self-regulatory arrangements without state intervention.

In Germany, the banking crisis of 1931 was an initial driver of the formalization of banking supervision, while the push toward the centralization of supervisory powers that enabled the government to counter the re-emergence of the largest banks completed the process of formalization after the Second World War (Krieghoff 2013: 124, 141).

The secondary banking crisis in the 1970s and several failures of international banks such as Germany's Herstatt Bank are generally viewed as the drivers of the formalization of banking supervision in the UK (Capie 2010: 611-616, 625-628). However, in our view, the main driver was financial globalization, as described later. ${ }^{15}$

\subsection{ECONOMIC CONTROL}

Following the Second World War, rapid reconstruction was the top priority in relation to economic policy because of the emerging Cold War between the US and the Soviet Union. This influenced the development of banking supervision in the post-war period.

The case of France provides a perfect example. The Banking Act of 1945 in France contained two essential elements: the nationalization of large banks and the separation of banking business into short-term and long-term activities, and into deposit-taking and investment-banking activities. Under the Banking Act of 1945, competition among banks declined significantly, and the banks were rarely allowed to open new branches. Until the mid-1960s, to provide sufficient finance for reconstruction, the French government preferred control of credit and systemic stability rather than competition (or efficiency).

Similarly, in Belgium, the supervisory agency (the Banking Commission), together with the central bank and the Treasury, made use of banking control regulations in the post-war period. In an effort to reduce

${ }^{15}$ In this regard, our view is basically in line with that of Lee (1979). 
the huge public debt that had been amassed during the war, a large share of bank credits was channeled toward the public sector. The ratio regulation introduced by the Banking Commission was one of the measures taken to reduce the massive public debt, as banks were obliged to hold considerable amounts of state bonds.

In Japan, the aim of banking supervision shifted toward systemic stability from 1949 in an attempt to promote the rapid recovery of the national economy. Under the US occupation (1945-1952), the authorities separated the banking business from the securities business and created a new category of special long-term lending banks. Although the aim of banking supervision did not formally alter, in practice the aim of banking supervision shifted from prudential supervision to the prevention of bank failures (Hotori et al. 2018: 115-116). With no commercial bank failures, Japan achieved high levels of economic growth during the period $1955-1973 .{ }^{16}$

\subsection{Financial Globalization}

Financial globalization and liberalization occurred from the 1970s onward. This ongoing trend appears to have been a driver of the formalization of banking supervision in several late-moving countries such as the UK.

In the case of the UK, pressure for reform emerged in the 1970s mainly from international forums such as the European Commission and the Basel Committee for Banking Supervision that led politicians to introduce institutional changes despite protests from both the commercial banks and the Bank of England. Following the introduction of the Banking Act of 1979, the role played by the Bank of England was gradually transformed into that of a semi-formal banking supervisor, although the level of enforcement remained "light-touch." Eventually, the financiers' desire to lift the UK's status to that of a global financial center prompted more formal banking supervision, as the previous informal supervision (colloquially known as "the governor's eyebrow") had proven ineffective in relation to foreign banks that were playing an increasing role in the UK under the Thatcher government. Margaret Thatcher's "Big Bang" regulatory reforms of 1987 completed the formalization of banking supervision

${ }^{16}$ Sweden is also an example of this type of transformation. 
in the UK. Under the Banking Act of 1987, the independent Board of Banking Supervision was formally created in November 1987.

Another example of an acceleration of the formalization process is the case of Belgium. In the post-war period, the role of the supervisory agency (the Banking Commission) was incrementally extended in response to the growing internationalization and despecialization of the financial system. In 1957, the Banking Commission assumed responsibility for the supervision of investment trusts, and in 1964, it was further empowered with the supervision of all of the institutions that received deposits from the public, such as consumer credit and mortgage companies.

$$
* * *
$$

In this chapter, the drivers of the process of formalization of banking supervision were examined from seven perspectives. We found that formalization took place in response to the shifting needs of the time/era, and that the formalization process was basically incremental. In the US, formalization began in response to the need for Civil War financing, while in Japan and Sweden it was closely linked to the organic development of the banking sector and the general public's increasing exposure to the banks as both depositors and borrowers. In Germany, Switzerland, and Belgium, the formalization process was triggered by the Great Depression in the early 1930s, although the specific forms of the crisis (e.g., bank runs, financial crises, economic crises, and political crises) varied considerably among the three countries. In France, the formalization process was linked to the Second World War and the subsequent control of the economy, while in the UK, progress toward financial globalization prompted a shift from informal to formal banking supervision. Notably, although financial crises are generally considered to have been the primary drivers of major regulatory and supervisory reforms, they did not always play a key role in the process of formalization of banking supervision. Additionally, it should be noted that from a historical perspective, regulation and supervision have not been "natural" responses to dysfunction in the banking system. Rather, the formalization of banking supervision was the product of complex political actions negotiated by relevant stakeholders with divergent interests in a specific social, political, and economic environment. 


\section{REFERENCES}

Allen, A.M., S.R. Cope, L.J.H. Dark, and H.J. Witheridge. 1938. Commercial banking legislation and control. London: MacMillan and Co.

Allen, F., and D. Gale. 2000. Comparing financial systems. Cambridge, MA: MIT Press.

Anonymous. 1859. How to mismanage a bank: A review of the Western Bank of Scotland. Edinburgh: Adam and Charles Black.

Bank of Japan. 1956. Nihon kin'yū shi siryō: Meiji Taishō hen (Historical materials of Japanese financial history in the Meiji and Taisho period), vol. 18. Tokyo: Ministry of Finance.

Berghoff, H., and I. Köhler. 2007. Redesigning a class of its own: Social and human capital formation in the German banking elite, 1870-1990. Financial History Review 14 (1): 63-87.

Calomiris, C.W., and L. Schweikart. 1991. The panic of 1857: Origins, transmission, and the containment. Journal of Economic History 51 (4): 807-834.

Capie, F. 2010. The Bank of England, 1950s to 1979. Cambridge: Cambridge University Press.

Capie, F., S. Fischer, C.A.E. Goodhart, and N. Schnadt. 1995. The future of central banking. Cambridge: Cambridge University Press.

Friedman, M., and A.J. Schwartz. 1963. A monetary history of the United States, 1867-1960. Princeton: Princeton University Press.

Gigliobianco, A., and G. Toniolo, eds. 2009. Financial market regulation in the wake of financial crises: the historical experience. Workshops and Conference Publication 1, Bank of Italy, Rome.

Goto, S. 1970. Nihon no kin'yū tōkei (Historical financial statistics in Japan). Tokyo: Toyo Keizai

Hall, P.A., and D.W. Soskice, eds. 2001. Varieties of capitalism: The institutional foundations of comparative advantage. Oxford: Oxford University Press.

Hotori, E. 2011. A history of prudential bank supervision in Japan: Organization, institutions and function, 1873-1942. Economia 62 (2): 29-41.

Hotori, E., F. Pasqualini, S. Prigent, J. Richard, and N. Praquin. 2018. Le juriste, le comptable et le banquier: regards croisés sur la prudence (The lawyer, the accountant and the banker: Views on prudence). Entreprises Et Histoire 92: $106-117$.

Hotori, E., and M. Wendschlag. 2019. The formalization of banking supervision in Japan and Sweden. Social Science Japan Journal 22 (2): 211-228.

Ishii, K. 2012. Teikokushugi nibon no taigai senryaku (Foreign strategy of imperial Japan, 1868-1937). Nagoya: University of Nagoya Press.

Kato, T. 1957. Honpō ginkō shiron (A history of banking in Japan). Tokyo: Tokyo University Press. 
Krieghoff, N.F. 2013. Banking regulation in a federal system: Lessons from American and German banking history. Dissertation, London School of Economics and Political Science.

La Porta, R., F. Lopez-de-Silanes, A. Shleifer, and R.W. Vishny. 1998. Law and finance. Journal of Political Economy 106 (6): 1113-1155.

Larson, M.J., K. Ward, and J.F. Wilson. 2010. Banking from Leeds, not London: Regional strategy and structure at the Yorkshire Penny Bank, 1859-1952. Accounting, Business \& Financial History 20 (2): 117-133.

Lee, P.T. 1979. Significant developments in the United Kingdom in 1979. Journal of Comparative Corporate Law and Securities Regulation 2: 335-337.

Osaka Asahi Shimbun, ed. 1928. Kin'yū kyōkō hiwa (Interview with ordinary depositors on financial crisis of 1927). Osaka: Ginko Mondai Kenkyu-kai.

Robertson, R. 1968. The Comptroller and bank supervision: A historical appraisal. Washington, DC: Office of the Comptroller of the Currency.

Ross, D.M., ed. 1998. History of banking II, 1844-1859, vol. 5. London: Pickering \& Chatto.

Takamura, N. 1996. Kaisha no tanjō (Birth of Japanese company system). Yoshikawa Kobunkan, Tokyo.

White, E.N. 2011. "To establish a more effective supervision of banking": How the birth of the Fed altered bank supervision. NBER Working Paper 16825.

- 2015. Stabilizing the national banking system 1864-1913: The role of bank examination. Paper presented at the 17th World Economic History Congress, Kyoto, 3-7 August.

Open Access This chapter is licensed under the terms of the Creative Commons Attribution 4.0 International License (http://creativecommons.org/licenses/ by $/ 4.0 /$ ), which permits use, sharing, adaptation, distribution and reproduction in any medium or format, as long as you give appropriate credit to the original author(s) and the source, provide a link to the Creative Commons license and indicate if changes were made.

The images or other third party material in this chapter are included in the chapter's Creative Commons license, unless indicated otherwise in a credit line to the material. If material is not included in the chapter's Creative Commons license and your intended use is not permitted by statutory regulation or exceeds the permitted use, you will need to obtain permission directly from the copyright holder.

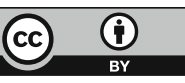

